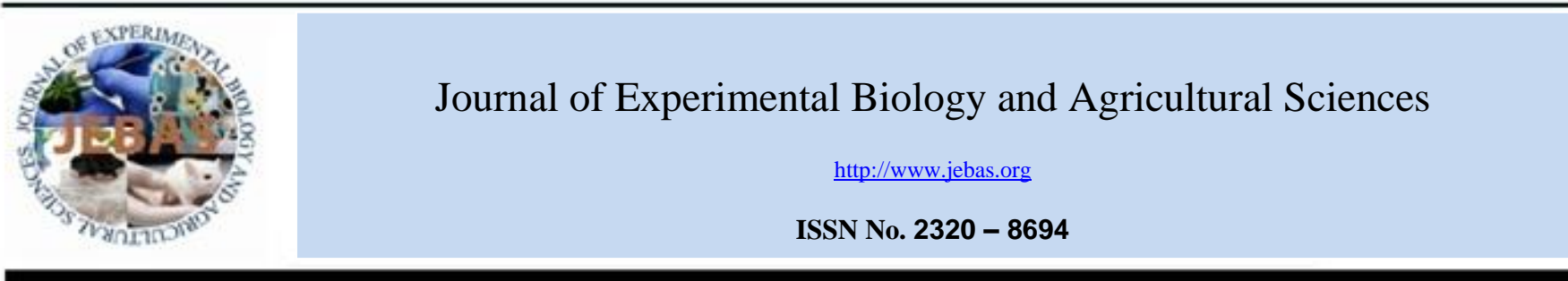

\title{
ASSESSMENT OF CONSTRAINTS PERCEIVED BY THE Bakarwal TRIBE IN SHEEP AND GOAT REARING PRACTICES IN JAMMU DISTRICT OF JAMMU AND KASHMIR
}

\author{
Farzana Choudhary, S. A. Khandi, Rayees Ahmed Bafanda*, Sheikh Umair Minhaj \\ Division of Veterinary and Animal Husbandry Extension Education, Sher-e-Kashmir University of Agricultural Sciences and Technology of Jammu(SKUAST-J), \\ R.S.PURA, Jammu-181102, India
}

Received - July 17, 2018; Revision - September 14, 2018; Accepted - September 29, 2018

Available Online - October 5, 2018

DOI: http://dx.doi.org/10.18006/2018.6(5).884.889

\section{KEYWORDS \\ Bakarwal tribe \\ Constraint \\ Sheep \\ Goat \\ Rearing practices}

\begin{abstract}
The present investigation was undertaken to assess the constraints perceived by the Bakarwal tribe in small ruminants rearing practices in Jammu district of Jammu and Kashmir. Multistage random sampling plan was followed for the selection of respondents. A well structured interview schedule was administered to 120 respondents randomly selected from the four selected blocks Marh, Satwari, Bhalwal and Dansal of Jammu district having good Bakarwal population. Data was collected through well structured interview schedule from the respondents either at their farm or home after proper testing of schedule and using appropriate scales. For evaluation of constraints the final schedule was divided into four broad areas namely management, feeding, breeding and health care. Each area of sheep and goat rearing practices contained 7 constraints in management, 10 in feeding, 6 in breeding and 8 in health care practices and the respondents were asked to rate them on three point continuum, based on seriousness of the perceived constraint. The constraints were then ranked based upon their mean percent score (MPS). The findings of present study revealed that for management practices, "migration" was perceived as most serious constraint $(95.28 \%$ ) ranked one followed by "limited resource availability for providing scientific housing to animals" $(92.5 \%)$ whereas "High cost of disinfectants" $(70.56 \%)$, was perceived as least serious constraint. In feeding practices, "scarcity of green fodder" was perceived as most serious constraint (93.89\%) which was followed by, "non- availability of pasture" (87.22\%). For breeding practices, "poor conception rate in animals" (90\%) ranked one was perceived as most serious
\end{abstract}

* Corresponding author

E-mail: rayeesahmed372@gmail.com (Rayees Ahmed Bafanda)

Peer review under responsibility of Journal of Experimental Biology and Agricultural Sciences.

Production and Hosting by Horizon Publisher India [HPI] (http://www.horizonpublisherindia.in/).

All rights reserved.
All the article published by Journal of Experimental Biology and Agricultural Sciences is licensed under a Creative Commons Attribution-NonCommercial 4.0 International License Based on a work at www.jebas.org.

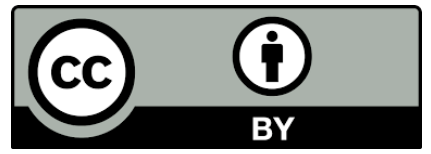


constraint while the lack of knowledge related to proper time for service" (67.78\%) was perceived as least serious constraint. In case of health care practices, "inefficient treatment of animals" (91.11\%) ranked one was perceived as most serious constraint by the respondents followed by, "vaccination facilities are not timely available" $(88.89 \%)$. On the other hand "high cost of treatment because of costly medicine" $(68.33 \%)$ was perceived as least serious constraint by the respondents.

\section{Introduction}

Sheep and goat from centuries have been an integral component of farming systems and most preferred species of small, marginal farmers and land less community due to lower initial investment, lesser risk, early return, high prolificacy, wide adaptability in various agro-climatic regions (Rakib, 1998). Round the year demand of sheep and goat products in market and their acceptability across religions also make it one of the preferred livestock species. Sheep and goats make important contribution to the stability of smallholder farming system by providing organic manure and financial resources for purchase of farm inputs and household needs (Singh et al., 2008). Sheep and goat have an inseparable identity with the farmers in India from time immemorial. Sheep or goat is considered as 'ATM for farmers', whenever they require money, they can sell the stock and furnish their needs (Belakeri et al., 2017). Sheep/goat rearing is a source of livelihood in the drought-prone rural areas of India. They constitute an important component of agriculture and economy of the farming community of India, especially those of the weaker sections among agriculturists (Singh et al., 2018). In addition they form substantially useful fraction if their total farm income particularly, when crops fail due to drought and other adverse conditions. Small ruminants sector provides cheap nutritional food of animal origin to millions of people in our country and also generate gainful employment, provides enormous amounts of organic manure.

Despite being a strong contributor to the income and livelihoods of the poorest segments of the society, the sector has remained largely underinvested and neglected on the institutional front. The sheep and goat sector production in India has low productivity purse which may be attributed to various factors like shortage of feed and fodder, lack of scientific knowledge, rearing nondescript breeds, low fertility (Landge, 2004). The sector is also constrained by various challenges such as poor breeds and poor management practices leading to low productivity, limited or no access to veterinary care leading to high mortality and issues related to marketing, securing of loan to meet their financial requirement, marketing of goat and non availability of goat health protection measures. (Anonymous, 2003). Keeping in view of above facts the present study was designed to find out the constraints perceived by Bakarwal tribe in Jammu District of Jammu and Kashmir state with the objective to analyze and document the constraints which hamper the adoption of improved sheep and goat rearing practices.

\section{Materials and Methods}

\subsection{Research Design}

Ex-post-facto research design was followed in the present study for assessment of constraints perceived by the Bakarwal tribe in sheep and goat rearing practices of Jammu District in Jammu and Kashmir State.

\subsection{Locale of Study}

Jammu and Kashmir State consists of three division's viz. Jammu, Kashmir and Ladakh. The state comprises of 22 districts of which Jammu is an important one and most populated comprises of 20 blocks with a population of $15,29,958$. The total population living in rural areas of Jammu district is 7, 64,945 (50\%) and majority of this population depends on agriculture and animal husbandry for their livelihood. Population of tribals in Jammu district is 69,193 (Census, 2011). It is located at $32.73{ }^{\circ} \mathrm{N}$ and $74.87^{\circ} \mathrm{E}$.

\subsection{Sampling Method}

Multistage random sampling plan was followed for the selection of respondents. Jammu district comprises of twenty blocks. Out of these four blocks namely Marh, Dansal, Satwari and Bhalwal were selected purposefully having predominant Bakarwal population. A list of respondents involved in sheep and goat rearing were prepared from the selected blocks. Thirty Bakarwals from each of the 4 selected blocks were selected randomly, making a sample size of 120 respondents.

\subsection{Data Collection}

A well structured interview schedule was developed using the package of practices of neighboring universities as "universe of content" after proper consultation with the members of Faculty of Veterinary Science and Animal Husbandry, SKUAST-Jammu for data collection using personal interview technique from the respondents either at their farm or home after proper testing of schedule and using appropriate scales. The final schedule was divided into four broad areas namely management, feeding, breeding and health care for evaluation of constraints in their respective sections. Each area of sheep and goat rearing practices contained 7 constraints in management, 10 in feeding, 6 in breeding and 8 in health care practices and the respondents were asked to rate 
them on three point continuum i.e. very serious (score $=3$ ), serious (score $=2$ ) and somewhat serious (score $=1$ ), based on seriousness of the perceived constraint. The constraints were then ranked based upon their mean percent score (MPS) which was calculated using the formula;

\section{MPS = Obtained score/ Maximum possible score $\mathbf{x} 100$}

\subsection{Statistical Analysis}

Data were coded, classified, tabulated and analyzed using the software; Statistical Package for the Social Science (SPSS 16.0). Frequencies, score obtained, mean score, rank and mean percent score (MPS) were worked out for meaningful interpretation

\section{Results and Discussion}

\subsection{Management constraints}

The item wise scores of management constraints as perceived by the Bakarwal tribe in sheep and goat rearing practices have been presented in table 1 . The data of the table 1 revealed that "migration" was perceived as most serious constraint (95.28\%) among the members of Bakarwal tribe, this was followed by, "limited resource availability for providing scientific housing to animals" (92.5\%) and "lack of knowledge about importance of sanitation and hygiene" (85.28\%). "High cost of disinfectants" (70.56\%), was perceived as least serious constraint. While, "lack of knowledge about cheap and scientific housing of animals" (82.78\%) ranked four which was followed by "lack of clean water in sufficient quantity round the year" $(82.22 \%)$ and "lack of knowledge about keeping up to date management records" (78.61\%). The results were in agreement with the findings of Khandi et al. (2011) and Jeelani et al. (2015) those who reported that the most important constraint faced by the Gujjars were lack of finance for improved management practices, lack of knowledge about cheap and scientific housing of animals and inadequate space for housing of diary animals. Similarly, Basunathe et al. (2010) revealed that the major reasons for the non-adoption or discontinuation of improved technologies were non-availability of service, lack of knowledge among farmers and withdrawal of free/subsidized services by government.

Table 1 Item wise scores of management constraints as perceived by the Bakarwal

\begin{tabular}{|c|c|c|c|c|c|}
\hline $\begin{array}{l}\text { S. } \\
\text { No. }\end{array}$ & Management constraints & $\begin{array}{c}\text { Score } \\
\text { Obtained }\end{array}$ & $\begin{array}{l}\text { Mean } \\
\text { Score }\end{array}$ & MPS & Rank \\
\hline 1. & Limited resource availability for providing scientific housing to animals & 333 & 2.78 & 92.5 & 2 \\
\hline 2. & Lack of knowledge about cheap and scientific housing of animals & 298 & 2.48 & 82.78 & 4 \\
\hline 3. & Lack of knowledge about importance of sanitation and hygiene & 307 & 2.56 & 85.28 & 3 \\
\hline 4. & Lack of clean water in sufficient quantity round the year & 296 & 2.47 & 82.22 & 5 \\
\hline 5. & Lack of knowledge about keeping up to date management records & 283 & 2.36 & 78.61 & 6 \\
\hline 6. & High cost of disinfectants & 254 & 2.12 & 70.56 & 7 \\
\hline 7. & Migration & 343 & 2.86 & 95.28 & 1 \\
\hline
\end{tabular}

Table 2 Item wise scores of feeding constraints as perceived by the Bakarwal

\begin{tabular}{|c|c|c|c|c|c|}
\hline S. No. & Feeding constraints & Score Obtained & Mean Score & MPS & Rank \\
\hline 1. & $\begin{array}{l}\text { Lack of knowledge regarding recommended feeding } \\
\text { practices }\end{array}$ & 276 & 2.3 & 76.67 & 5 \\
\hline 2. & Scarcity of dry fodder & 252 & 2.1 & 70 & 8 \\
\hline 3. & High cost involved in purchase of concentrates & 268 & 2.23 & 74.44 & 6 \\
\hline 4. & Scarcity of green fodder & 338 & 2.82 & 93.89 & 1 \\
\hline 5. & Non availability of pasture & 314 & 2.62 & 87.22 & 2 \\
\hline 6. & $\begin{array}{l}\text { Distant location of market for purchase of concentrate } \\
\text { and mineral mixture }\end{array}$ & 238 & 1.98 & 66.11 & 9 \\
\hline 7. & Lack of water for irrigation facilities for growing fodder & 306 & 2.55 & 85 & 3 \\
\hline 8. & High cost of mineral mixture/ feed supplement & 266 & 2.22 & 73.89 & 7 \\
\hline 9. & Lack of knowledge about preservation of fodder & 304 & 2.53 & 84.44 & 4 \\
\hline 10. & $\begin{array}{l}\text { Non-availability of qualified personnel to train about } \\
\text { better feeding of animals }\end{array}$ & 226 & 1.88 & 62.78 & 10 \\
\hline
\end{tabular}


Table 3 Item wise scores of breeding constraints as perceived by the Bakarwal

\begin{tabular}{|clcccc|}
\hline S. No. & \multicolumn{1}{c}{ Breeding practices } & Score Obtained & Mean Score & MPS & Rank \\
\hline 1. & $\begin{array}{l}\text { Inadequate knowledge to detect heat signs in } \\
\text { animals }\end{array}$ & 262 & 2.18 & $\mathbf{7 2 . 7 8}$ & 4 \\
\hline 2. & Lack of knowledge of proper time for service & 244 & 2.03 & $\mathbf{6 7 . 7 8}$ & 6 \\
\hline 3. & Poor conception rate in animals & 324 & 2.7 & $\mathbf{9 0}$ & 1 \\
\hline 4. & Lack of good breedable animals & 296 & 2.47 & $\mathbf{8 2 . 2 2}$ & 2 \\
\hline 5. & Misconceptions about using crossbred animals & 276 & 2.3 & $\mathbf{7 6 . 6 7}$ & 3 \\
\hline 6. & $\begin{array}{l}\text { Untrained and inexperienced } \\
\text { staff in veterinary dispensary }\end{array}$ & 258 & 2.15 & $\mathbf{7 1 . 6 7}$ & 5 \\
\hline
\end{tabular}

Table 4 Item wise scores of health care constraints as perceived by the Bakarwal

\begin{tabular}{|clcccc|}
\hline S. No. & \multicolumn{1}{c}{ Health care practices } & Score Obtained & Mean Score & MPS & Rank \\
\hline 1. & Non- availability of veterinary Dispensary & 264 & 2.2 & $\mathbf{7 3 . 3 3}$ & 7 \\
\hline 2. & High cost of treatment because of costly medicine & 246 & 2.05 & $\mathbf{6 8 . 3 3}$ & 8 \\
\hline 3. & $\begin{array}{l}\text { Lack of knowledge of schedule of deworming } \\
\text { practices of animals }\end{array}$ & 292 & 2.43 & $\mathbf{8 1 . 1 1}$ & 5 \\
\hline 4. & Vaccination facilities are not timely available & 320 & 2.67 & $\mathbf{8 8 . 8 9}$ & 2 \\
\hline 5. & $\begin{array}{l}\text { Lack of knowledge of common contagious, diseases } \\
\text { their causes and control measures }\end{array}$ & 312 & 2.6 & $\mathbf{8 6 . 6 7}$ & 3 \\
\hline 6. & $\begin{array}{l}\text { Inadequate number of doctors at veterinary hospitals/ } \\
\text { Dispensary }\end{array}$ & 276 & 2.3 & $\mathbf{7 6 . 6 7}$ & 6 \\
\hline 7. & Ineffective treatment of Animals & 328 & 2.73 & $\mathbf{9 1 . 1 1}$ & 1 \\
\hline 8. & Self treated at home & 298 & 2.48 & $\mathbf{8 2 . 7 8}$ & 4 \\
\hline
\end{tabular}

\subsection{Feeding constraints}

The data of table 2 revealed the item wise scores feeding constraints as perceived by the Bakarwal tribe in sheep and goat rearing practices. In feeding practices, "scarcity of green fodder" was perceived as most serious constraint (93.89\%) followed by, "non- availability of pasture" (87.22\%) and "lack of water for irrigation facilities for growing fodder" (85\%). "Non-availability of qualified personnel to train about better feeding of animals" was perceived as least serious constraint $(62.78 \%)$ by the respondents. "Lack of knowledge about preservation of fodder" $(84.44 \%)$ was ranked four in feeding constraints followed by " lack of knowledge regarding recommended feeding practices" (76.67\%), "high cost involved in purchase of concentrates" (74.44\%), "high cost of mineral mixture/feed supplement" (73.89\%), "scarcity of dry fodder"(70\%) and “ distant location of market for purchase of concentrate and mineral mixture" (66.11\%), respectively. Similarly, Singh \& Sharma (2004) reported that the major constraints were shortage of feeds and fodder during dry season, traditional method of feeding, scattered and low land holding, poor animal productivity i.e., low milk production, large number of non descript type animal, lack of breeding bull, poor extension services and monopoly gender role in livestock activity. Thorat \& Kulkarni (1994) reported that high cost of feed and fodder was the major constraint faced by the dairy farmers. Inadequate supply of fodder and feed to the animals, lack of knowledge regarding preparation of silage and scientific feeding of animals were the other constraints faced by the farmers.

\subsection{Breeding constraints}

The finding in table 3 revealed that under the breeding constraints the "poor conception rate in animals" (90\%) was perceived as most serious constraint this was followed by, "lack of good breedable animals" $(82.22 \%)$ and "misconceptions about using crossbred animals" (76.67\%). "Lack of knowledge of proper time for service" (67.78\%) was perceived as least serious constraint by the respondents. Fourth rank was allotted to "inadequate knowledge to detect heat signs of animals" (72.78\%) and fifth rank to "untrained and inexperienced staff in veterinary dispensary" (71.67\%). Similarly, Umar et al. (2011) reported that the major constraints faced by the dairy farmers, regarding breeding practices were ill equipped artificial insemination 
services, repeat breeding and lack of pedigree bull for natural services, followed by low genetic potential of local animals, poor knowledge of artificial insemination services and poor availability of resources to maintain superior breed of milch animals. The perception of Artificial insemination being an unnatural process may be related to the traditional values and difficult persuasion of Gujjars about a new practice due to their poor literacy rate and low social and extension contacts. Mohi \& Bhatti (2006) found that poor results of artificial insemination unavailability or distant location of artificial insemination centre, inadequate facilities at artificial insemination centre were perceived as most serious constraints in adoption of breeding practices.

\subsection{Health care constraints}

On perusal of table 4, most serious health care constraints perceived by Bakarwal tribe was "inefficient treatment of animals" (91.11\%). This was followed by, "vaccination facilities are not timely available" (88.89\%) and "lack of knowledge of common contagious diseases, their causes and control measures" $(86.67 \%)$. On the other hand "high cost of treatment because of costly medicine" (68.33\%) was perceived as least serious constraint by the respondents. Fourth rank was allotted to "self treated at home" $(82.78 \%)$, followed by "lack of knowledge of schedule of deworming practices of animals"(81.11\%), “ inadequate number of doctors at veterinary hospitals" (76.67\%)" and "non- availability of veterinary dispensary" (73.33\%), respectively. Similarly, Keshava \& Mandape (2001) found that major problems faced by farmers in dairy farming were proneness of animals to diseases, costly cattle feeds, unavailability of veterinary facilities and regular milk market. Tiwari et al. (2003) reported that majority of the respondents felt improved feeds as costlier and non availability of hospital as most serious constraint along with other constraints.

\section{Conclusions}

Sheep and Goat rearing is one of the most remunerative farming enterprises in India. There are large number of constraints which were affecting sheep and goat rearing practices adopted by bakarwal tribes which were ultimately responsible for income in small ruminants rearing. The findings of study revealed that majority of the respondents perceived that "migration", "scarcity of green fodder", costly feeds, "poor conception rate in animals" and "inefficient treatment of animals" as most serious constraints in management, feeding, breeding and health care, respectively. To overcome these constraints there is a need of alternative models for delivery of health services that are less costly and need for less costly feeds and additives. Scientists, experts should organize a campaign with actual demonstration regarding the scientific preparation \& storage of feeds \& silage making. It will help to avoid the problem of scarcity of green fodder. More emphasis should be given on mobile veterinary clinic to provide veterinary services for convenience and at door. Beside this there is a need to improve knowledge, skills, and awareness, motivated by the change agent to overcome the constraints faced by Bakarwal tribe. Extension agencies should make an attempt to develop teams of Para-extension worker who through proper training programmes could be effective in providing information $\&$ improve the skills of the Bakarwal tribe rearing sheep and goats.

\section{Conflict of Interest : Nil}

\section{References}

Anonymous (2003) The Hindu Survey of Indian Agriculture. Kasture and Sons Ltd, Chennai.

Basunathe VK, Sawarkar SW, Sasidhar PVK (2010) Adoption of dairy production technologies and implications for dairy development in India. Outlook Agriculture 39: 134-140.

Belakeri P, Mohankumar S, Bhajantri S, Nishath C (2017) Effectiveness of Sheep and Goat Training Programme in terms of Knowledge Gain among Livestock Farmers of Karnataka. International Journal of Pure and Applied Bioscience 5: 31-34.

Census of India (2001) Ministry of Home Affairs, Government of India. Available on http://www.census2011.co.in access on $29^{\text {th }}$ August, 2018.

Jeelani R, Khandi SA, Kumar P, Bhadwal M, Beig MY (2015) Constraints perceived by the Gujjars regarding adoption of improved animal husbandry practices. Journal of Animal Research 5: 269-275.

Keshav, Mandape MK (2001) Analysis of potentials and problems of dairy farming in north Bihar. Indian Journal of Animal Science 71: 577-579.

Khandi SA, Gautam, Hamdani SA, Kumar P, Bhadwal MS (2011) Constraints perceived by Gujjars (Pastoralists) in adopting improved animal husbandry practices. Journal of Research, SKUAST-Jammu 10: 17-24.

Landge S (2004) Study of goat production practices by goat keepers of Kandhar block in Nanded district. M.V.Sc. Thesis submitted to the University of MAFSU, Nagpur.

Rakib A (1998) Grazing resources and livestock production with special references to goat production. Indian Journal of Animal Sciences 68:846-848.

Mohi AK, Bhatti JS (2006) Constraints encountered by dairy farmers in adoption of improved dairy farming practices. Journal of Dairy Foods Home Science 25: 47-50. 
Singh N, Sharma FL (2004) Knowledge of dairy cooperative society members and non-members about advanced dairy production technology. Rajasthan Journal of Extension Education 12-13: 142-145.

Singh MK, Rai B, Singh P, Singh PK, Singh NP (2008) Goat production status in different agro-climatic regions of India: an overview. Indian Journal of Small Ruminants 14: 48-70.

Singh D, Kerketta P, Kumar A, Neeraj (2018) Constraints in goat and sheep husbandry practices in Allahabad district of Uttar Pradesh, India. Journal of Pharmacognosy and
Phytochemistry 7: 1132-1135.

Thorat DR, Kulkarni BR (1994) Constraints faced by the dairy farmers. Maharashtra Journal of Extension Education 13: 305-306.

Tiwari RK, Bisen JP, Sharma PN (2003) A study on constraints and suggestions regarding adoption of improved animal husbandry practices in Chhattisgagh plains. Indian Research Journal of Extension Education 3: 9-12.

Umar J, Kumar B, Kumar S (2011) Constraints perceived by farmers in adopting scientificdairy farming practices in Madhuni district of Bihar. Research Journal Agriculture Science 2: 142-145. 